\title{
ANALISIS STRUKTUR STOMATA PADA DAUN BEBERAPA TUMBUHAN HIDROFIT SEBAGAI MATERI BAHAN AJAR MATA KULIAH ANATOMI TUMBUHAN
}

\author{
Wina Dyah Puspita Sari dan Herkules \\ Jurusan Biologi, FMIPA, Universitas Negeri Medan \\ Email : w_dyahpuspitasari@yahoo.co.id
}

\begin{abstract}
ABSTRAK
Penelitian ini bertujuan untuk menganalisis struktur jaringan epidermis dan derivatnya pada daun beberapa tumbuhan hidrofit yaitu tumbuhan Eichornia crassipes L, Nelumbo nucifera Gaertn., Pistia stratiotes L dan Nymphaea pubescens Willd. Metode yang digunakan ada penelitian ini adalah Metode deskriptif untuk menggambarkan struktur sel epidermis dan derivatnya (stomata dan trikoma) daun pada beberapa tumbuhan yang hidup dipermukan air berdasarkan pengamatan irisan membujur dan melintang sel-sel epidermis pada permukaan atas dan bawah daun dengan mikroskop cahaya. Hasil penelitian menunjukkan bahwa seluruh jenis tumbuhan hidrofit yang diteliti memiliki stomata dengan tipe anomositik. Eichornia crassipes L memiliki stomata pada kedua permukaannya (amfistomatik), sedangkan ketiga jenis lainnya hanya memiliki stomata pada bagian atas saja (Epistomatik), Kerapatan dan indeks stomata tertinggi terdapat pada jenis Nelumbo nucifera Gaertn. sebesar 1389.51 dan 0.36, diikuti oleh Nymphaea pubescens Willd. sebesar 1350.92 dan 0.4. Hasil penelitian ini dapat menjadi media pembelajaran pada mata kuliah dan praktikum Anatomi tumbuhan.
\end{abstract}

Kata kunci: epidermis, derivat epidermis, stomata, tumbuhan hidrofit

\section{ANALYSIS OF STOMATA STRUCTURE ON SOME LEAF OF HIDROFIT PLANTS AS A MATERIAL OF COURSE PLANTS ANATOMY}

\begin{abstract}
This study aims to analyze the structure of epidermal tissue and its derivatives on leaves of several hydrophytic plants ie Eichornia crassipes L, Nelumbo nucifera Gaertn., Pistia stratiotes L and Nymphaea pubescens Willd. The method used in this research is descriptive method to describe the cell structure of the epidermis and its derivatives (stomata and trichoma) of leaves in some living plants in water based on observation of longitudinal slices and transverse epidermal cells on the top and bottom surfaces of the leaves by light microscope. The results showed that all hydrophytic plants studied had stomata with anomocytic type. Eichornia crassipes L has stomata on both surfaces (amfistomatik), whereas the other three types have only stomata on top only (Epistomatik), while the other three types have only the top stomata (Epistomatik), the highest density and stomatal index are found in the Nelumbo nucifera Gaertn type. of 1389.51 and 0.36, followed by Nymphaea pubescens Willd. of 1350.92 and 0.4 . The results of this study can be a medium of learning on the course and practicum Anatomy of plants.
\end{abstract}

Keywords : epidermis, derivatives epidermis, stomata, hydrofit plant

\section{Pendahuluan}

Epidermis merupakan lapisan sel-sel paling luar dan menutupi permukaan daun, bunga, buah, biji, batang dan akar. Berdasarkan ontogeninya, epidermis berasal dari jaringan meristematik yaitu protoderm. Epidermis berfungsi sebagai pelindung bagian dalam organ tumbuhan. Berdasarkan fungsinya, epidermis dapat berkembang dan mengalami modifikasi seperti stomata dan trikomata.

Setiap jenis tumbuhan mempunyai struktur sel epidermis yang berbeda. Perbedaan struktur sel epidermis yang dimaksud dapat berupa bentuk dan susunan sel epidermis, letak atau kedudukan stomata terhadap sel tetangga, arah membukanya stomata, bentuk stomata, jumlah sel epidermis dan stomata, jarak antara stomata, panjang sel epidermis dan stomata.

Stomata biasanya ditemukan pada bagian tumbuhan yang berhubungan dengan udara terutama di daun, batang dan rizoma. Stomata umumnya terdapat pada permukaan bawah daun, tetapi ada beberapa spesies tumbuhan dengan stomata pada permukaan atas dan bawah daun.

Tumbuhan yang hidup di air merupakan bagian dari vegetasi penghuni bumi ini, yang 
media tumbuhnya adalah perairan. Penyebarannya meliputi perairan air tawar, payau sampai ke lautan dengan beraneka ragam jenis, bentuk dan sifatnya. Jika memperhatikan sifat dan posisi hidupnya di perairan, tumbuhan air dapat dibedakan dalam 4 jenis, yaitu: tanaman air yang hidup pada bagian tepian perairan, tumbuhan air yang hidup pada bagian permukaan perairan, tumbuhan air yang hidup melayang di dalam perairan, dan tumbuhan air yang tumbuh pada dasar perairan. Faktor-faktor yang mempengaruhi tumbuhan air itu terutama ialah suhu, udara, dan konsentrasi serta komposisi garam-garam dalam air. Ciri strukural yang paling mencolok pada daun-daun tumbuhan air adalah penyusutan jaringan-jaringan penunjang dan pelindung, berkurangnya jumlah jaringan pembuluh, khususnya xylem, dan adanya ruangan udara. (Firdaus, 2015)

Stomata pada tumbuhan yang daunnya mengapung dipermukaan air, hanya terdapat pada permukaan atas saja. Hal ini berkaitan dengan pemasukan dan pengeluaran air yang dilakukan daun dalam melaksanakan fungsi transpirasi dan respirasi. Kajian struktur sel epidermis dan stomata daun khususnya pada tumbuhan air belum diketahui secara jelas dan masih terbatas mengenai keberadaan letak stomatanya saja. Oleh sebab itu penelitian ini perlu dilakukan untuk memberikan informasi ilmiah tentang struktur sel epidermis dan stomata tumbuhan air.

\section{Bahan dan Metode}

Metode yang dipakai untuk pengamatan jaringan epidermis adalah metode penyayatan dengan membuat preparat permanen yang disediakan dengan metode paraffin Sass. Metode yang dipakai untuk mengamati stomata di permukaan daun adalah metode replika.

Kegiatan penelitian ini dibagi menjadi tiga tahap, yaitu: 1) pengambilan sampel tumbuhan hidrofit, 2) pembuatan preparat, 3) pengamatan dan pengukuran, serta 4) pembuatan foto mikroskopis dari penampang yang telah dibuat. Pengambilan sampel tumbuhan hidrofit

Pada tahap ini, dilakukan pengambilan sampel tumbuhan hidrofit yang hidupnya mengapung di permukaan air.

\section{Pengukuran Indeks Stomata}

Pengamatan indeks stomata pada daun dilakukan dengan cara sebagai berikut :

Daun difiksasi dalam alkohol 70\%, kemudian larutan fiksatif dibuang diganti dengan akuades. Selanjutnya direndam dalam larutan $\mathrm{HNO}_{3} \quad 25 \%$ selama 15-30 menit untuk menghancurkan jaringan mesofil. Sebelum disayat menggunakan silet, daun tersebut terlebih dahulu dicuci menggunakan akuades. Untuk menghilangkan klorofil dari mesofil yang terikat, sayatan epidermis direndam dalam larutan bayclin selama 1-5 menit kemudian dicuci dengan akuades. Sayatan epidermis yang telah didapatkan kemudian diwarnai dengan pewarna safranin selama 1 menit kemudian dicuci dengan akuades. Sediaan berupa lapisan epidermis diletakkan di atas gelas objek kemudian ditetesi gliserin $10 \%$ dan ditutup dengan gelas penutup.

Peubah yang diamati yaitu jumlah stomata tiap bidang, penghitungan dilakukan pada 10 bidang pandang yang berbeda.

Berikut rumus penghitungan stomata:

Kerapatan stomata $=\quad$ Jumlah stomata Satuan luas bidang pandang

Indeks stomata $=$ Jumlah stomata Jumlah stomata+sel epidermis

(Lestari, 2005).

\section{Pembuatan foto mikroskopis}

Setelah preparat diamati, dilakukan pembuatan foto mikroskopis dengan menggunakan kamera mikroskop.

\section{Analisis Data}

Data pengamatan jaringan epidermis daun diuraikan secara deskriptif, jumlah sel epidermis dan stomata, jarak antara stomata dan panjang sel epidermis dan stomata.

\section{Hasil Dan Pembahasan}

Pada penelitian ini digunakan 4 (empat) jenis tumbuhan air yang diperoleh dari beberapa lokasi, seperti yang terlihat pada tabel dibawah ini :

Tabel 1. Jenis Tumbuhan Air

\begin{tabular}{|l|l|l|}
\hline No. & Jenis & Lokasi pengambilan \\
\hline 1. & Nelumbo nucifera Gaertn. & Kolam di Universitas Medan Area \\
\hline 2. & Pistia stratiotes L & Kolam di Universitas Medan Area \\
\hline 3. & Nymphaea pubescens Willd. & Kolam Farmasi di Universitas Sumatera Utara \\
\hline 4. & Eichornia crassipes L. & Kolam Farmasi di Universitas Sumatera Utara \\
\hline
\end{tabular}


Keberadaan Stomata Pada Permukaan Daun Dari hasil pengamatan dengan menggunakan metode replika, keberadaan stomata dapat dilihat pada tabel 2 dibawah ini.

Tabel. 2 Keberadaan Stomata pada permukaan daun

\begin{tabular}{|l|l|c|c|}
\hline \multirow{2}{*}{ No. } & \multicolumn{1}{|c|}{ Jenis } & \multicolumn{2}{c|}{ Keberadaan Stomata } \\
\cline { 3 - 4 } & & Daun adaksial & Daun abaksial \\
\hline 1. & Nelumbo nucifera Gaertn. & + & - \\
\hline 2. & Pistia stratiotes L & + & - \\
\hline 3. & Nymphaea pubescens Willd. & + & - \\
\hline 4. & Eichornia crassipes L. & + \\
\hline
\end{tabular}

Ket.

+ : ada:

- : tidak ada

Dari tabel 2, dapat dilihat bahwa pada tumbuhan Eichornia crassipes L memiliki stomata pada kedua permukaan yaitu pada permukaan adaksial dan permukaan abaksial, sedangkan Nelumbo nucifera Gaertn., Pistia stratiotes L dan Nymphaea pubescens Willd., hanya memiliki stomata pada bagian abaksial saja. Hal ini disebabkan oleh adapatasi yang dimiliki oleh tumbuhan hidrofit terhadap lingkungannya, Tumbuhan air memiliki cara untuk beradaptasi dengan lingkungannya seperti daun yang ada pada tumbuhan air lebih besar, akar yang tidak terlalu panjang, tidak mempunyai lapisan lilin, dan stomata yang pada umumnya besar serta letak stomatanya berada di atas permukaan daun (Eka, 2012).

Daun yang lebar pada tumbuhan air dikarenakan stomata yang banyak sehingga hal ini dapat mempercepat proses fotosintesis. Lapisan lilin juga tidak dimiliki oleh daun pada tumbuhan air di karenakan lapisan lilin tersebut hanya akan memperlambat proses penguapan pada tumbuhan air dan letak stomata yang ada dibagian atas dikarenakan stomata tersebut langsung berhadapan dengan atmosfer sehingga mempercepat proses transpirasi (Eka, 2012).

\section{Gambaran Epidermis dan Stomata}

Dari penelitian yang telah dilakukan, diperoleh gambaran epidermis dan stomata pada beberapa jenis tumbuhan air.

Stomata Eichornia crassipes L.

Dari gambaran stomata Eichornia crassipes L., pada bagian permukaan atas dan permukaan bawahnya memiliki stomata dengan tipe anomositik. Tipe anomositik adalah tipe stomata dengan sel penutup berbentuk ginjal dikelilingi oleh sel-sel tetangga dengan jumlah yang tidak tertentu; bentuk sel tetangga sama dengan bentuk sel epidermis. Eichornia crassipes L. merupakan tumbuhan yang berada di habitat berair, namun helaian daunnya tidak bersentuhan langsung dengan air.

Lestari (2005), menyatakan bahwa bentuk stomata yang berbeda ini dipengaruhi oleh kondisi lingkungan, habitat tanaman tersebut dan anatomi tanaman itu sendiri.

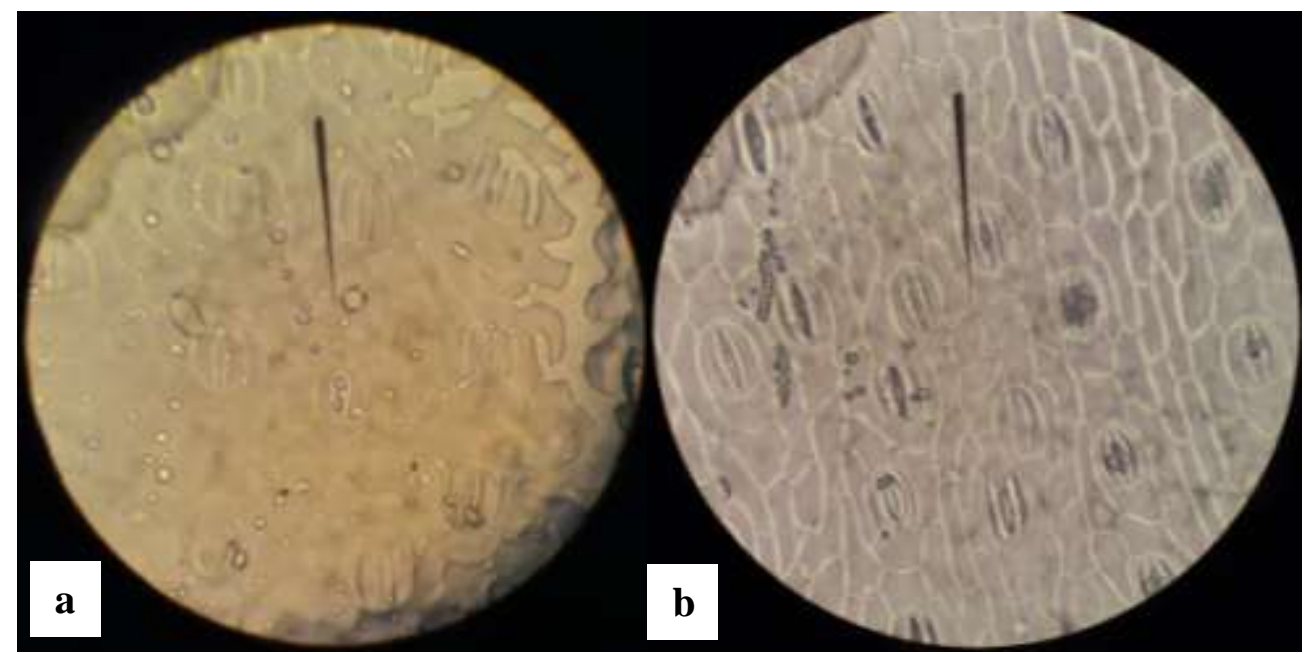

Gambar 5. Eichornia crassipes L. a) Daun adaksial, b) Daun abaksial 


\section{Stomata Nelumbo nucifera Gaertn}

Dari preparat awetan Nelumbo nucifera Gaertn,,stomata hanya terdapat pada bagian permukaan atas saja. Tipe stomata yang terdapat pada jenis ini adalah tipe anomositik. Helaian daun Nelumbo nucifera Gaertn. ada yang terdapat langsung bersentuhan dengan air, namun ada yang disangga dengan tangkai daun yang panjang.

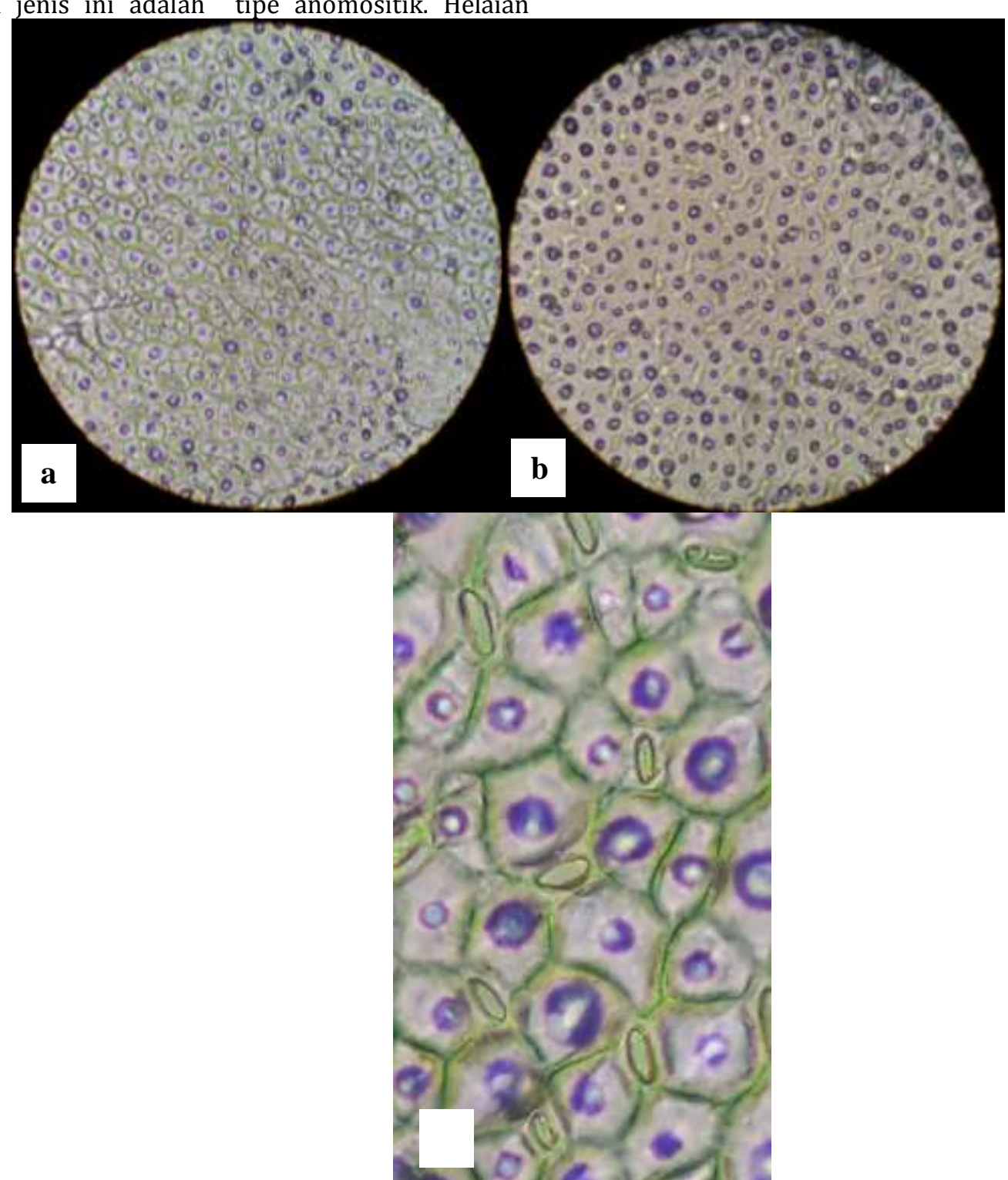

Gambar 6. Nelumbo nucifera Gaertn. a) Daun adaksial, b) Daun abaksial,

c) Perbesaran stomata

\section{Stomata Pistia stratiotes L}

Dari preparat awetan Pistia stratiotes L, seperti yang terlihat pada Gambar 6, stomata hanya terdapat pada bagian permukaan atas saja. Tipe stomata yang terdapat pada jenis ini adalah tipe anomositik. Pada sel epidermis Pistia stratiotes L., memiliki ruangan antar sel yang besar, sehingga tampak sel epidermis yang satu dengan sel epidermis yang lain terpisah satu sama lain. Pada helaian daun Pistia stratiotes L. ini memiliki trikoma yang banyak dan halus, sulit untuk mendapatkan gambaran stomata yang jelas. 


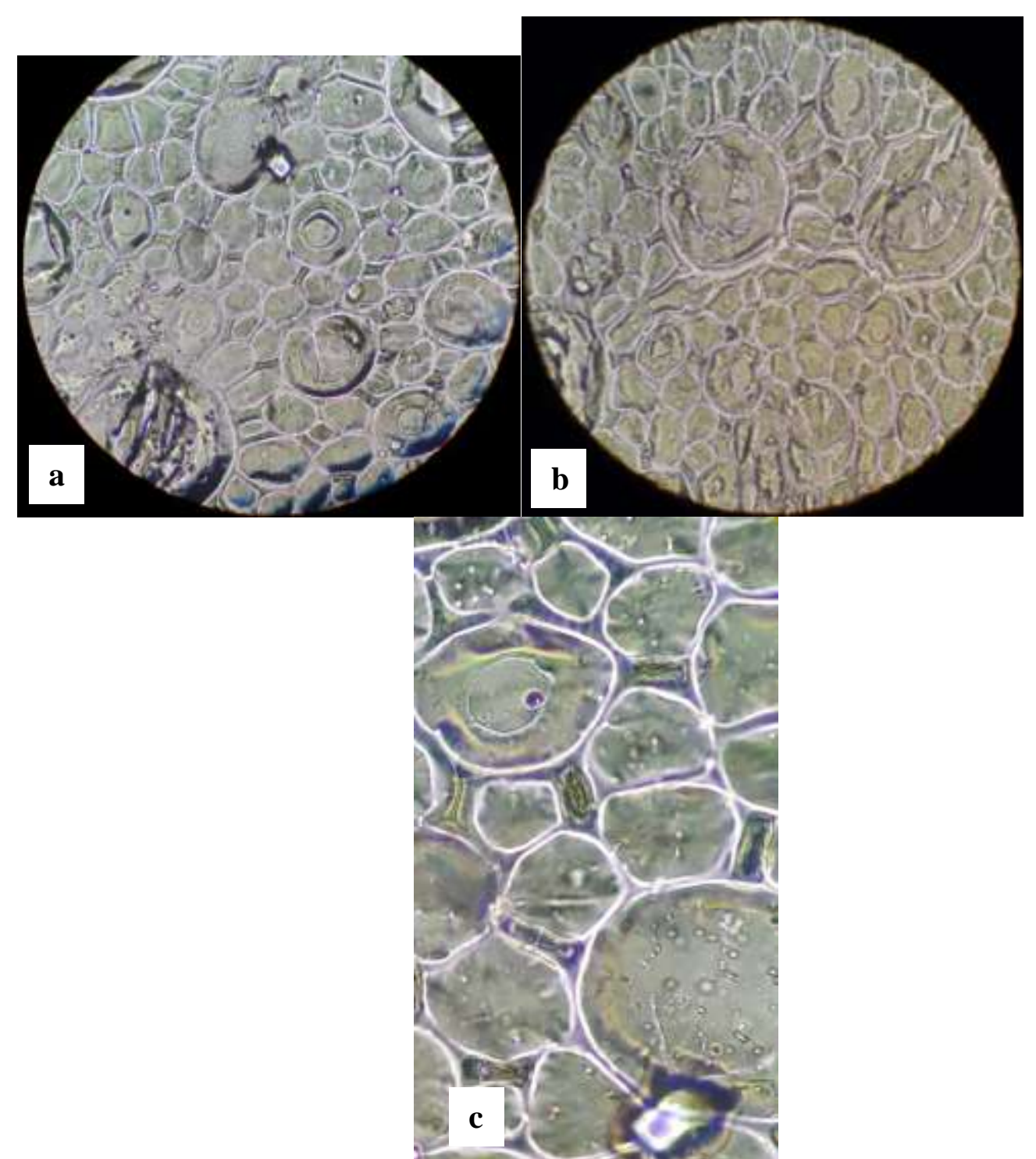

Gambar 7. Pistia stratiotes L. a) Daun adaksial, b) Daun abaksial, c) Perbesaran stomata

\section{Stomata Nymphaea pubescens Willd}

Dari preparat awetan Nymphaea pubescens Willd, stomata hanya terdapat pada bagian permukaan atas saja. Tipe stomata yang terdapat pada jenis ini adalah tipe anomositik. Helaian daun Nymphaea pubescens Willd. terdapat langsung bersentuhan dengan air.

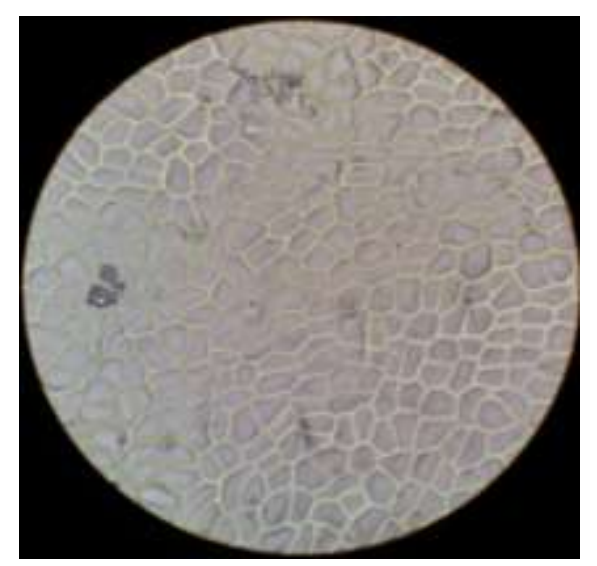

Gambar 8. Nymphaea pubescens Willd. a) Daun abaksial 


\section{Kerapatan dan Indeks Stomata}

Dari preparat yang telah diamati, diperoleh hasil kerapatan dan indeks stomata seperti yang tertera pada Tabel.3

Tabel 3. Kerapatan dan Indeks Stomata

\begin{tabular}{|l|l|c|c|c|c|}
\hline \multirow{2}{*}{ No. } & \multicolumn{1}{|c|}{ Jenis } & \multicolumn{2}{c|}{ Kerapatan Stomata } & \multicolumn{2}{c|}{ Indeks Stomata } \\
\cline { 3 - 6 } & & $\begin{array}{c}\text { Daun } \\
\text { Adaksial }\end{array}$ & $\begin{array}{c}\text { Daun } \\
\text { Abaksial }\end{array}$ & $\begin{array}{c}\text { Daun } \\
\text { Adaksial }\end{array}$ & $\begin{array}{c}\text { Daun } \\
\text { Abaksial }\end{array}$ \\
\hline 1. & Nelumbo nucifera Gaertn. & 1389.51 & - & 0.36 & - \\
\hline 2. & Pistia stratiotes L & 154.39 & - & 0.15 & - \\
\hline 3. & Nymphaea pubescens Willd. & 1350.92 & - & 0.40 & - \\
\hline 4. & Eichornia crassipes L. & 83.63 & 115.79 & 0.35 & 0.14 \\
\hline
\end{tabular}

Masing- masing dari tumbuhan air tersebut memiliki kerapatan stomata dan indeks stomata yang berbeda. Nelumbo nucifera Gaertn., memiliki kerapatan stomata yang tertinggi yaitu 1389.51 dengan indeks stomata sebesar 0.36. Nymphaea pubescens Willd. memiliki kerapatan stomata 1350,.92 dengan indeks stomata sebesar 0.4. Eichornia crassipes L. memiliki kerapatan stomata yang terendah jika dibandingkan dengan tiga tumbuhan air lainnya. Dikarenakan ukuran stomata dan sel epidermisnya yang lebih besar jika dibandingkan dengan yang lain.

\section{Kesimpulan}

Dari hasil penelitian yang telah dilaksanakan, dapat diperoleh kesimpulan sebagai berikut :

1. Seluruh jenis tumbuhan hidrofit yang diteliti memiliki stomata dengan tipe anomositik.

2. Eichornia crassipes L memiliki stomata pada kedua permukaannya (amfistomatik), sedangkan ketiga jenis lainnya hanya memiliki stomata pada bagian atas saja (Epistomatik).

3. Kerapatan dan indeks stomata tertinggi terdapat pada jenis Nelumbo nucifera Gaertn. sebesar 1389.51 dan 0.36, diikuti olehn Nymphaea pubescens Willd. sebesar 1350.92 dan 0.4.

\section{Saran}

1. Perlu dilakukan penelitian lanjutan mengenai perbandingan morfologi dan anatomi antara tumbuhan-tumbuhan hidrofit.

\section{DAFTAR PUSTAKA}

Fahn, A. 1990. Anatomi Tumbuhan. Gajah Mada Press. Yogyakarta

Hidayat, E. B. 1996. Anatomi Tumbuhan Berbiji . Itb Press. Bandung

Lestari, E.G. 2006. Hubungan Antara Kerapatan Stomata Dengan Ketahanan Kekeringan Pada Somaklon Padi Gajahmungkur, Towuti, dan IR 64. JurnalBiodiversitas. Volume 7 Nomor 1 Halaman 44-48

Mulyani, S. 2006. Anatomi Tumbuhan. Penerbit Kansius. Yogyakarta

Nugroho, L.H., Purnomo dan Sunardi. 2006. Struktur Dan Perkembangan Tumbuhan. Penebar Swadaya. Jakarta

Ratnawati,E.2012.TranspirasiTumbuhan.Http://ek aratnawati2492.wordpress.com/2012/11 /12/Transpirasipada- Tumbuhan-/2. Diakses Tanggal 12 November 2012.

Setjo, Kartini, Saptasari M, Dan Sulisetjono. 2004. Anatomi. Universitas Negeri Malang. Malang 